Maria Rosaria Ferrarese. Full Professor of Sociology of Law in the Università degli Studi di Cagliari and Sociology of Law and Economic Life at Scuola Nazionale dell'Amministrazione - Roma, where she teaches Sociology of Law and Economic life. Her research interests focus on transformations in the legal landscape, due to the process of globalization; legal issues related to global financial crisis; relationship between law and market; new legal subjects of governance; crisis of representative democracy. Contact: ferraresemr@libero.it 


\title{
GOVERNANCE:
}

\section{A Soft Revolution with Hard Political and Legal Effects}

\author{
Maria Rosaria Ferrarese \\ Università degli Studi di Cagliari \\ Scuola Nazionale dell'Amministrazione di Roma
}

Reception date $7^{\text {th }}$ March 2014; acceptance date $9^{\text {th }}$ April 2014. This article is the result of research activities held at the Dipartimento di Giurisprudenza (Università degli Studi di Cagliari) and at Scuola Nazionale dell'Amministrazione, Roma.

\section{Abstract}

The basic assumption of this article is that governance marks a departure from the two pillars of the project of modernity: representative democracy and legislative institutions. Governance, as a complex institutional phenomenon that goes far beyond participation, has significantly deconstructed the two main points of reference of modern democracy, that is, people and territory. Furthermore, its inclusive and open nature has not prevented the emergence of a dark side, made of exclusive modes: a theater without publicity. From the perspective of transformations, this article highlights the emergence of a changing and fluid normativity, one capable of adapting to the specificity and the variability of situations and processes, inevitably eclipsing the primacy of the legislation itself.

\section{Keywords}

Governance, representative democracy, legal globalization, inclusiveness

\section{Resumen}

El supuesto básico de este artículo es que la gobernanza señala un alejamiento de los dos pilares del proyecto moderno: la democracia representativa y las instituciones legislativas. La gobernanza, como fenómeno institucional complejo, que va mucho mas 
allá de la participación, ha desestructurado sensiblemente los dos principales puntos de referencia de la democracia moderna: pueblo y territorio. Su trato inclusivo y abierto no ha impedido el surgimiento de un lado oscuro, hecho de modos exclusivos: un teatro sin publicidad. Desde la perspectiva de las transformaciones este artículo pone en evidencia la emergencia de una normatividad cambiante y fluida, capaz de adaptarse a las especificidad y a la variabilidad de situaciones y procesos, ofuscando inevitablemente la misma primacía de la legislación.

\section{Palabras clave}

Gobernanza, democracia representativa, globalización juridica, inclusividad

\section{Governance as a Soft Revolution}

When we think of governance we usually tend to think of devices shared between the public and the private. We also think of less codified and more flexible modes of producing rules of conduct on the local, national, international and global planes. The vast literature on this topic has brought into focus the main characteristics of governance, usually comparing and contrasting it to the notion of 'government.' Moreover, it has brought attention to the different issues relating to it, above all that of the 'democratic deficit'. Yet by focusing on 'governance', understood through its idealtypical characteristics as well as its actual phenomenology, the impact of its emergence on the nature of the modern institutional scene is generally overlooked. In the following pages a specific angle will be adopted in order to seek a path towards reform, a reform that is actually intrinsic to and implied by governance itself. As it will be argued, the latter notion does not adhere to a carefully and rationally designed model; this notwithstanding, it does contain a great potential for reform.

Viewed from such a perspective, governance itself can be considered a 'soft revolution' because, all in modifying in depth the pre-existing political and institutional context, it has not openly attacked the supporting structures - i.e. the parliamentary

1. J. N. Rosenau, E.-O. Czempiel, Governance without Government: Order and Change in World Politics, Cambridge University Press, Cambridge, 1992. Also see O. Treib, H. Baehr, G. Falkner, "Modes of Governance: Towards a Conceptual Clarification", in Journal of European Public Policy, 14, 2007, pp. 1-20. 
and government institutions - and the rituals of electoral democracy on which the representative system is built. So, while the idea of the complete survival of such structures endures, in point of fact the elements defining the phase in which they developed have considerably changed. Soft revolution, implied by 'governance', has transformed legal and political as well as national and international scenarios essentially through a fragmentation of the state, the materialization of which had once signalled the advent of a coherent conception of power. Thus a new era characterized by the "incompleteness of power" has seen the day. ${ }^{2}$ In it governance processes are crucial and, as in the Middle Ages analysed by Paolo Grossi, new “intermediate bodies" seem to flourish. ${ }^{3}$

\section{The Many Defies Faced by the Modern Political and Legal Project}

The basic coordinates of the modern political project are to be found in the eminently representative nature of democracy, while the juridical coordinates are exemplified, especially in Europe, by the primacy of statute law over the executive and judicial activities. The combination of representative democracy and legislation was particularly especially tight in continental Europe, where the "written law shaped by the sovereign proved to be co-essential to the very existence of [its] body politic." ${ }^{4}$ The state used legislation as its main legal currency, in the shadow of the jus publicum europeum. ${ }^{5}$ As Hobbes remarked, "[T] he common-wealth is the Legislator. But the Common-wealth is no Person, nor has capacity to do anything, but by the Representative, (that is, the Sovereign) and therefore the Sovereign is the sole Legislator." ${ }^{6}$

Of course the emergence of governance practices did not abruptly unsettle such a scheme. Some of the changes were gradual and were related to that unrestrainable process of challenges to representative democracy that a vast literature has analysed from different angles. ${ }^{7}$ Similarly, the downsizing of legislative institutions gradually

2. P. Grossi, L'ordine giuridico medievale, Laterza, Roma-Bari, 1997, and Id., Europa del diritto, Laterza, Roma-Bari, 2007.

3. Grossi makes the case that the incompleteness of power generates the "proliferation of intermediate societies"; see P. Grossi, Europa del diritto, p. 17.

4. P. G. Monateri, Geopolitica del diritto. Genesi, governo e dissoluzione dei corpi politici, Laterza, Roma-Bari, 2013, p. 111.

5. C. Schmitt, Der Nomos der Erde. im Völkerrecht des Ius Publicum Europaeum, Greven, Köln, 1950, and P.P. Portinaro, La crisi dello Jus publicum europaeum. Saggio su Carl Schmitt, Edizioni di Comunità, Milano, 1982.

6. T. Hobbes, Leviathan, Cambridge University Press, Cambridge, 1996, p. 184 (chap. 26).

7. It suffice to refer, here, to B. Manin, Principes du gouvernement représentatif, Calmann-Lévy, Paris, 1995. Also see: N. Urbinati, Representative Democracy: Principles and Genealogy, The University of Chicago Press, Chicago, 2006; Lo scettro senza il re. Partecipazione e rappresentanza nelle democrazie moderne, Donzelli, Roma, 2009, and see also Democrazia rappresentativa. Sovranità e controllo dei poteri, Donzelli, Roma, 2010; Democrazia in diretta. Le nuove sfide alla rappresentanza, Feltrinelli, Milano, 2013. 
took place throughout the twentieth century, when the weight of the executives grew at the expense of the legislative power. That weight has further increased in connection with globalization processes. ${ }^{8}$ But governance produces one more double distancing: of democracy from its capacity to represent the people, and of law from the legislative process itself. This stems from the profound incompatibility of governance practices with the two pillars of the modern political project.

The representative idea of democracy was consistent with the emergence of mass politics and with a political culture that did not distinguish between the 'I' and the 'us'. Moreover, it was incompatible with the notion of 'intermediate societies'. In the main, it was used to offer to a political majority a strong decision-making capacity, necessary to adequately tackle the issues pertaining to the collective social and economic life. In Europe, the idea of representative democracy, pivoting around the opposition between majority and minority, showed at the beginning a sharp penchant towards the majority, which was considered decisive and even, in cases, was assimilated to unanimity itself.' ${ }^{9}$ But Kelsen already renames the majority principle in terms of a 'majority-minority' dichotomy, since that the entire parliamentary procedure is based on the idea of a 'compromise' between majority and minority. ${ }^{10}$ Now, over time, the relationship between majorities and minorities has undergone several transformations, ${ }^{11}$ to the point of establishing the paradox that democracies that rely on are undemocratic. In other words, in the too vast majorities political sphere, at a time when the interest towards 'majoritarian democracy' was increasing, the importance to be assigned to minorities groups and individuals as a mark of good democratic practices has increased. From a different perspective, representative democracy definitely had an elitist penchant, since it entrusted the mandate largely to the 'conscience' of the representatives themselves. ${ }^{12}$ These could dispose of it freely and without constraints - a fact that, in turn, reflected the existence of a gap, theoretical if not actual, between voters and elected.

\footnotetext{
8. For example, Saskia Sassen makes the case that " $[\mathrm{I}] \mathrm{n}$ the United States the state tightened its power function, even as other parts of the government lost power": S. Sassen, Territory, Authority, Rights, Princeton University Press, Princeton (N.J.), 2006, p. 162.

9. On this point, see P. Rosanvallon, La légitimité démocratique. Impartialité, réflexivité, proximité, Seuil, Paris, 2009. See especially chap. 1.

10. H. Kelsen, Vom Wesen unt Wert der Demokratie ${ }^{2}$, J.B.C. Mohr, Tübingen, 1929, p. 53

11. On this issue, besides Rosanvallon's book referred to in note 28, see also E. Ruffini, Il principio maggioritario, Adelphi, Milano, 1976, and A. Pizzorusso, Minoranze e maggioranze, Einaudi, Torino, 1993. Also see F. Galgano, La forza del numero e la legge della ragione. Storia del principio di maggioranza, Il Mulino, Bologna, 2007.

12. See, for example, A. Pizzorno, 'Introduzione', in A. Pizzorno, (ed.), La democrazia di fronte allo stato. Una discussione sulle difficoltà della politica moderna, Feltrinelli, Milano, 2010.
} 
The specificity of the European scenario forces us to come to terms with the different Anglo-Saxon and especially American context. ${ }^{13}$ There, the consistency itself of the 'body politic' is different and incomparable to what Hobbes represented through the mythical Leviathan and that was encapsulated by Schmitt in the notion of "the autonomy of the political", that is, of "its absolute intensity and its qualitatively uniqueness." 14 On this point, suffice it to consider on the one hand how in the United States the majoritarian culture has grown weaker and, on the other, how the legal physiognomy of American democracy has been entrusted mainly to the judge-made law, rather than to the legislation. ${ }^{15}$ The United States has always been inclined to challenge the idea of representative democracy, and has shown a clear penchant towards the principle and practices of the binding mandate. ${ }^{16}$ Yet even in Europe, already before the advent of modern governance, that model had been affected in various ways by different social and political movements and impulses. First and foremost, there was the tendency towards Caesarism, a phenomenon already identified by Weber as a germ lingering within the modern body politic and impinging its rationality. ${ }^{17}$ The proliferation of populist $\mathrm{t}^{18}$ and personalistic drives ${ }^{19}$ represents a hidden risk for the representative capacity of democracy in our own time. But even the different elitist conceptions of democracy, which have brought the focus onto the competition between elites, as in Schumpeter's reading, ${ }^{20}$ or on 'poliarchy' as Dahl has understood it, ${ }^{21}$ contributed to minimize the actual representative value. No less significant challenges to the notion and the process of representation stemmed from the increasing social complexity and from the underlying network of interests characterizing the postmodern society. ${ }^{22}$ The increasing

13. On this, see P. Monateri, Geopolitica del diritto, Laterza, Roma-Bari, 2013. Also see M. R. Ferrarese, La governance tra politica e diritto, Il Mulino, Bologna, 2010.

14. See C. Galli, Genealogia della politica. Carl Schmitt e la crisi del pensiero politico moderno, Il Mulino, Bologna, 2010, p. 737.

15. U. Mattei, Il modello di common law, Giappichelli, Torino, 1996.

16. So, referring to America, Tocqueville noted that "very frequently the electors, having elected their delegate, will lay down a plan of behaviors and will impose upon him a certain number of positive commitments in could in no way avoid", A. de Tocqueville, Democracy in America, Penguin, London, 2003, p. 288.

17. The famous Weberian distinction between traditional, legal-rational and charismatic power in M. Weber, Economy and Society. An Outline of Interpretive Sociology, University of California Press, Berkeley-Los Angeles-London, 1978, pp. 212301, carries within the idea of an implicit combination of these three forms, especially between the charismatic and the legal-rational power. See G. Rebuffa, Nel crepuscolo della democrazia, Il Mulino, Bologna, 1991.

18. Y. Meny and Y. Surel, Par le peuple, pour le peuple. Le populisme et les démocraties, Fayard, Paris, 2000. Also see the latest analysis by N. Urbinati, Democrazia sfigurata. Il popolo tra opinione e verità, Università Bocconi Editore, Milano, 2014, especially pp. 177 and ff.

19. M. Calise, Il partito personale. I due corpi del leader, Laterza, Roma-Bari, 2010.

20. J. A. Schumpeter, Capitalism, Socialism and Democracy, Allen and Unwin, London, 1943.

21. R. A. Dahl, Polyarchy. Participation and Opposition, Yale University Press, New Haven and London, 1971.

22. Yet Santi Romano, already in 1909, noted that the "progressive organization on the basis of the particular interests of society, which ever more loses its atomistic nature", S. Romano, Lo stato moderno e la sua crisi. Discorso per l'inaugurazione 
articulation of interests tended to be reflected in the sphere of political representation, transforming the representative into amere performer of increasingly more specific and partial mandates. This has led to the emergence, as for example in Italy, of the phenomenon of 'decoding' and the swelling in number of laws made for favouring specific groups or individuals. ${ }^{23}$

Not surprisingly, in the 1980s neo-corporatism theories saw an increasing capacity of interests groups to undermine the fullness of the representative mandate, dividing it into a congeries of particularistic mandates. ${ }^{24}$ Even the 'deliberative' conception of democracy can be considered a precedent on the road leading to the crisis of representation. ${ }^{25}$ In fact, following Habermassian assumptions and focusing on public discussion as crucial to the democratic process, it contributed to shift the focus from top to bottom. Moreover, the many sub-varieties of deliberative democracy, which called attention to a plurality of deliberative forums and focus groups, essentially sought to counter representative bodies. Finally, the hypothesis of an 'electronic democracy', already analysed by the existing literature, ${ }^{26}$ and examined and arrived at the Italian Parliament in 2013, is perhaps the most explicit challenge to the classical representative rationale. ${ }^{27}$

Each one of these perspectives has produced effects within modern democracies, so that, it might be said, today different perspectives and components coexist. Elements of traditional representation, now almost residual, coexist with elements of corporate and lobbies representation, along with expressions of 'deliberative' democracy, but also with many other forms of 'direct' democracy. Correspondingly, law is pluralized into different 'images'28 and various 'truths. ${ }^{29}$

dell'anno accademico dell'Università di Pisa, Vannucchi, Pisa, 1909, p. 28.

23. N. Irti, L'età della decodificazione, Giuffrè, Milano, 1978, and L'età della decodificazione vent'anni dopo, Giuffrè, Milano, 1999.

24. On this issue, see P.C. Schmitter, Neo-corporatism and the State, European University Institute, Florence, 1984; E. Gualmini, Le rendite del neocorporativismo. Politiche pubbliche e contrattazione privata nel mercato tedesco e italiano, Rubbettino, Roma, 1997 and W. Streeck, The Study of Interest Groups: Before 'the Century' and After, in C. Crouck, W. Streeck (eds.), The Diversity of Democracy: Corporatism, Social Order and Political Conflict, Edward Elgar, London, 2006.

25. On the point, J. Elster (ed.), Deliberative Democracy, Cambridge University Press, Cambridge, 1998. Also see J. Bohman, W. Rehg, Deliberative Democracy, The MIT Press, Cambridge (Mass.), 1997, and L. Bobbio, "Democrazia dei cittadini e democrazia deliberativa", in Cosmopolis, 8, 2013. Also see A. Floridia, La democrazia deliberativa. Teorie, processi e sistemi, Carocci, Roma, 2012.

26. Besides S. Rodotà, Tecnopolitica. La democrazia e le nuove tecnologie della comunicazione, Laterza, Roma-Bari, 2004, also see D. Pittèri, Democrazia elettronica, Laterza, Roma-Bari, 2007, and G. Tocci, Governance urbana e democrazia elettronica, Rubettino, Roma, 2006.

27. See R. Biorcio, P. Natale, Politica a 5 stelle. Idee, storia e strategie del movimento di Grillo, Feltrinelli, Milano, 2013, and S. Rodotà, Il mondo nella rete. Quali i diritti, quali i vicoli, Laterza, Roma-Bari, 2014.

28. A. Tucci, Immagini del diritto. Tra fattualità istituzionalistica e agency, Giappichelli, Torino, 2012.

29. F. Mancuso, Le 'verità’ del diritto. Pluralismo dei valori e legittimità, Giappichelli, Torino, 2013. 


\section{Democracy and Governance: Coinciding or Diverging Scenarios?}

The impact of governance on the representative nature of democracy has been particularly incisive in at least two ways. First, governance has substantially deconstructed the two main references of modern democracy, that is, 'people' and 'territory'. Consequently, the scenarios of governance and democracy no longer coincide with one another as regards the territory or the people. Second, the highlighting of the 'inclusive' character governance, ${ }^{30}$ which characterizes it as a mode of government open and reassuring, has helped hide a darker side of governance, made of 'exclusive' rather than 'inclusive' modes. I will consider this second cause of divergence between democracy and governance in the following section. Now, let us concentrate on the first reason of dissociation.

The dissociation of governance from people and territory has not adequately been examined by the existing literature. If democracy might be defined as "a government of all and for all adult individuals with no other distinction; individuals who live closely together or co-exist in a given space and give themselves specific laws as if they were strangers to one other", ${ }^{31}$ one can see that in the notion itself of state there was an "aspect of unrelatedness and artificiality" ${ }^{32}$ that paralleled the general and abstract character of the laws. Although territory and people may appear as concrete entities, it was precisely the modern state that disembodied them by neutralizing corporate orders - as noted by Grossi. ${ }^{33}$

The detachment from people and territory produced by governance entails getting closer to less artificial entities. In this sense, it is part of a broader movement towards more 'natural' actions, motives, and laws. ${ }^{34}$ Foucault brilliantly understood the factors that could deconstruct the two entities. In passing, it is worth noting that until the sixteenth century populations and individuals were merely "variables par rapport au

\footnotetext{
30. Inclusiveness, understood as the participation of private individuals to public decisions, is analysed as a distinctive trait of governance (together with 'effectiveness' and 'interactivity') in M. R. Ferrarese, La governance tra politica e diritto, pp. 51 and ff.

31. This is the definition offered by N. Urbinati, Democrazia in diretta, p. 22.

32. Ibid., p. 23.

33. Grossi stresses the importance of the annihilation of corporative bodies brought about in 1789 by Le Chapelier's decree, and the subversion that the abstract notion of equality produced on "the notion of political representation": P. Grossi, L'Europa del diritto, p. 131.

34. On this, N. Irti, L'uso giuridico della natura, Laterza, Roma-Bari, 2013. On the complex relationship and entangle between nature and art, see A. Catania, F. Mancuso (eds.), Natura e artificio. Norme, corpi e soggetti tra politica e diritto, Mimesis, Milano, 2011, and especially L. Bazzicalupo, "Dalla natura all'artificio e ritorno. Un breve circuito a proposito di norma”, pp. 11-24. Laura Bazzicalupo, furthermore, discusses the notion of 'naturalized capitalism' in her 'L'immaginario della crisi e lo spettro del cambiamento: Falso movimento', in L. Bazzicalupo, A. Tucci (eds.), Il grande crollo. Ė possibile un governo della crisi economica?, Mimesis, Milano, 2010, pp. 15-34. Also see D. Carusi, L'ordine naturale delle cose, Giappichelli, Torino, 2011.
} 
territoire." ${ }^{35}$ It was in a 1555 work $^{36}$ that Foucault sought the traces of a different conception of government, one that was inspired by the Christian pastorate and which he called "gouvernamentalité". Far from being based on the principle of common good, it was a notion construed around the idea of "fin convenable", implying a "plurality of specific ends." ${ }^{37}$ It is no coincidence that this conception has often been juxtaposed with that of governance.

In the literature concerning globalization, much attention has been devoted to the restructuring of spaces, even in the legal sense, ${ }^{38}$ rather than the restructuring of territory' and 'people' as such. ${ }^{39}$ Among exception is the work by Saskia Sassen, who addresses the issue of territory by deconstructing its meaning. After a long historical excursion, Sassen reaches the conclusion that "key dynamics of the current transformation tend toward disaggregation, in a reversal of the earlier period that saw the formation of the nation-state." ${ }^{40}$ According to Giddens, 'disassembling' is a key word in the modernization process, ${ }^{41}$ but it gains a new significance in the global political and institutional dynamic: "Disassembling the national" becomes the guideline of a spatial restructuring that rejects the classic divide between national and international as well as that between public and private. ${ }^{42}$ Through the creation of so-called "transnational networks", ${ }^{43}$ and "multiple for a for scientific, cultural and business communities and the formation of international private organizations," 44 the new world of governance comes into being. Its political rationality rejects measurable and intangible quantities - as were people and territory - and inaugurates an "unprecedented compatibility of heterogeneous elements - so different from the coherence sought after by modern legal systems." ${ }^{45}$ Through governance, in short, a new mode of flexible and decentralized government is asserted, one that does not explicitly deal with problems in general and abstract terms, but

35. M. Foucault, Sécurité, territoire, population. Cours au Collège de France 1977-1978, Gallimard-Seuil, Paris, 2004, p. 99.

36. Reference is to de La Perrière's Miroir politique, one of the works that animated the debate ensuing the publication of Machiavelli's Principe. The work is referred to and examined by Foucault in his Sécurité, territoire, population, pp. 94 and ff. 37. M. Foucault, Sécurité, territoire, population, p. 102.

38. See, for example, S. Cassese, Lo spazio giuridico globale, Laterza, Roma-Bari, 2002, and M.R. Ferrarese, Diritto sconfinato. Inventiva giuridica e spazi nel mondo globale, Laterza, Roma-Bari, 2006.

39. On the issue of territory, see A. Di Martino, Il territorio: dallo stato-nazione alla globalizzazione. Sfide e prospettive dello stato costituzionale aperto, Giuffrè, Milano, 2010.

40. S. Sassen, Territory, Authority, Rights, p. 7.

41. A. Giddens, The Consequences of Modernity, Polity, Cambridge, 1990.

42. S. Sassen, Territory, Authority, Rights, pp. 143 and ff.

43. On this, see A.M. Slaughter, The Real New World Order, Princeton University Press, Princeton, 2004. On the importance of networking and joining-up processes for democratic governance, see M. Bevir, Democratic Governance, Princeton University Press, Princeton, 2010, pp. 183 and ff.

44. S. Sassen, Territory, Authority, Rights, p. 151.

45. A. Tucci '(Dis)aggregazioni', in A. Tucci (ed.), Disaggregazioni. Forme e spazi di governance, Mimesis, Milano-Udine, 2013, p. 11. 
faces them with interventions pursuing specific targets and addressing specific recipients. This also means that "numerous actors construct governance differently as they operate against the background of diverse traditions." ${ }^{36}$ People and territory, because of their unitary and indivisible character, are no longer functional, and, without being openly questioned, become the object of a reworking and partial deactivation. Every specific governance process builds different parts of 'people' and 'territory' to meet the needs of different recipients. Furthermore, this does not necessarily deploy itself within the boundaries of the state. Indeed, as it is well known, governance processes that take place under the banner of international organizations are increasingly crucial in shaping the political face of our world. ${ }^{47}$ In this sense, governance is linked to the process of re-invention and multiplication of spaces through a network-like legal organization typical of globalization, ${ }^{48}$ taking on a horizontal rather than a vertical dimension, ${ }^{49}$ and presenting a sort of 'marbled' aspect, with lines and colours intersecting in complex ways..$^{50}$

The undoing of people and territory implemented by governance processes shows a clear deviation from the arithmetic approach to democracy which was based on the opposition between majority and minority. It is a significant challenge to it. Since it becomes necessary to offer articulated legal answers to the complex network of needs of individuals and groups, then it is the concept of 'sociological minorities' that comes into play, rather than that of 'political minorities. ${ }^{51}$ The dichotomy majority/ minority is irrelevant to governance. As a matter of, governance actually contributes to concealing it, all in working effectively to further the rights of minority groups. In doing so, it encourages the emergence of new types of 'intermediate bodies', favouring anti-majoritarian tendencies. Moreover, in this direction, governance is paralleled by constitutionalism, which assigns a prominent position to the guarantee of fundamental rights of individual, groups and minorities, ${ }^{52}$ and makes of these an insurmountable limit to politics, to the point of establishing a sphere of 'undecidability. ${ }^{53}$

\footnotetext{
46. M. Bevir, Democratic governance, p. 86.

47. On global governance, see J.L. Dunoff and J.P. Trachtman (eds.), Constitutionalism, international Law and Global Governance, Cambridge University Press, Cambridge, 2009.

48. See F. Ost, M. van de Kerchove, De la pyramide au réseau? Pour une théorie dialectique du droit, Publications des Facultés Universitaires Saint-Louis, Bruxelles, 2002.

49. M. R. Ferrarese, "Il diritto orizzontale. L'ordinamento giuridico globale secondo Sabino Cassese", in Politica del diritto, 2, 2007, pp. 639-652.

50. Cassese uses this image in his book The Global Polity: Global Dimensions of Democracy and the Rule of Law, Global Law Press, Sevilla, 2012.

51. On the point, A. Pizzorusso, Minoranze e maggioranze.

52. See M. R. Ferrarese, La governance tra politica e diritto, Il Mulino, Bologna, 2010, pp. 103 and ff.

53. On this, see L. Ferrajoli, La democrazia attraverso i diritti, Roma-Bari, Laterza, 2013.
} 


\section{Governance: A Theatre Without Publicity}

On a national and international level, the detachment of people and territory implemented by the processes of governance manifests itself through the incessant production of ever new decision-making scenarios concerning various topics and involving different actors who maintain varying relationships with the government. Speaking of 'scenarios' helps emphasize the existence of a contradictory relationship between governance and a specific theatrical genre of which it represents, at once, an elation and a rejection. In fact, on the one hand governance might be understood as a sort of travelling theatre, which assembles its scenes each time in a different way, in different places, using different pieces and even different actors for each performance. On the other hand, it largely relinquishes the 'public' character so typical of theatre performances, especially of travelling theatres. In the past, classic state institutions, and especially the parliament, considered a theatricality that coincided with publicity to be their hallmark. When Bagehot evoked the theatrical nature of the British Parliament, assigning to it a crucial role in educating the citizens, he was referring to the public character of that institution. ${ }^{54}$ With governance, we find ourselves facing a theatricality that is disassociated from full publicity. The latter is variable, and in any case is smaller than that of government, that is, of classics state institutions. Theatricality, understood as an act performed 'publicly' and endowed with meaningful symbolic character, is simply absent. So, beyond the democratic deficit produced by governance so often pointed at by the existing literature, a decrease of the symbolic capacity of the fora engaged in strictly functional decision-making processes should also be noted.

A vast European literature, starting from Hobbes, has accustomed us to considering the state as an entity endowed with symbolic and mystical meanings, ${ }^{55}$ mysterious,${ }^{56}$ and full of theological connotations. ${ }^{57}$ The strong functionalist impression of governance breaks this narrative of the state and its institutions. The symbolic elements become less evident. It might be argued that repeated calls for 'transparency' coming from

54. "The distinguishing quality of Parliamentary Government is, that in each stage of a public transaction there is a discussion; that the public assist at this discussion; that it can, through Parliament, turn out an administration which is not doing as it likes, and can put in an administration which will do as it likes" W. Bagehot, The English Constitution, Oxford University Press, London, 1873, p. 34.

55. The issue has been examined from a Durkheimian viewpoint by P. Bourdieu, Sur l'État. Cours au Collège de France (1989-1992), Seuil, Paris, 2012.

56. E. H. Kantorovicz, The King's Two Bodies: A Study in Mediaeval Political Theology, Princeton University Press, Princeton, 1995.

57. C. Schmitt, The Concept of the Political, Rutgers University Press, New Brunswick, 1996. 
international governance play a surrogate role, and represent a legitimizing mechanism, to the traditional symbolic role of the state. The 'eye of the law' is no longer watching. ${ }^{58}$ On the contrary, it requires that both subjects and practices become visible by asking them, for example, to fight corruption through internal mechanisms, ${ }^{59}$ always ready to meet with a searching eye. In this sense, governance is a further step on the road to secularization and the loss of the theological and mystical character of public institutions.

Governance is shaped around an economic rationale. It is no coincidence that Agamben speaks of an "economic theology" that has taken the place of the "political theology". If the latter expressed itself through the "legislative omnipotence", the "economic theology" mirrors the rationale of the oikonomia understood as "the running of the household" which calls for "decisions and arrangements for facing each time specific problems that concern the functional order (taxis) of the various parts of the oikos." ${ }^{\prime 60}$ It is this essentially domestic and managerial nature of global governance, no longer responding to any episteme, that renders it seemingly effective and, by such a token, ends hiding its political nature and its explicitly ideological approach to the interpretation and solution of problems.

\section{Governance Between Inclusions...}

Governance is often seen as the hallmark of a new form of democracy 'from below' called 'participative' democracy. ${ }^{61}$ Its tight relationship with participation has contributed to understanding governance primarily as a means of strengthening democracy and as a specific decision-making mode with unprecedented 'inclusive' capacities. Governance practices have multiplied in number, while the ensuing processes of participation have allowed a variety of public and private stakeholders to partake to public decisions. Individuals might represent the different needs of citizens, groups, professional associations, business enterprises, NGOs and social movements of various kinds. Public subjects include states, regions, different types of judicial bodies, and especially international networks and organizations. Such an enlarged participation has

58. M. Stolleis, Das Auge des Gesetzes: Geschichte einer Metapher, C.H. Beck Verlag, München, 2004.

59. See the interesting work by A. Garapon, P. Servan-Schreiber (eds.), Deals de justice. Le marché américain de l'obéissance mondialisée, PUF, Paris, 2013.

60. G. Agamben, Il regno e la gloria. Per una genealogia teologica dell'economia e del governo, Neri Pozza, Firenze, 2007 , p. 31. 61. See D. Held, Models of Democracy, Polity, Cambridge, 1987, and M. Paci, Welfare locale e democrazia partecipativa, Il Mulino, Bologna, 2008; also see U. Allegretti, La democrazia partecipativa. Esperienze e prospettive in Italia e in Europa, Firenze University Press, Firenze, 2010. 
played an essential role in presenting governance as an inclusive and welcoming mode of rule, one admitting a greater number and a wider variety of actors than those that representative democracy allowed for. This, it meets the expectations of a new form of democracy capable of giving a voice to actors who, in the past, where at the margins of society. International governance also allows and encourages the introduction of new levels of participation, marking the entry of civil society in public decision-making processes not only in societies that have scarce familiarity with democratic practices, but also in countries with longer democratic traditions.

Participation in governance processes can be of various kinds. They may encompass various procedures and different levels and types of government (local, national, international and global). They might involve law-making, regulatory, judicial, or disputes-settlement processes by 'quasi-judicial' bodies. It might even be possible to conceive of a form of 'participation rights' that are, however, particularly varied, protean and in most instances not invokable before a judge. As suggested by Cassese, these are scattered in a sort of 'labyrinth' in which it is particularly difficult to extricate oneself. Furthermore, "the divide between participation and consultation, participation and negotiation, participation and co-operation are far from clear"; emerging, here, is the continuity, if not the identification, of participation and negotiation. ${ }^{62}$

In particular, participation has been promoted by major international organizations. The World Bank has made participation a key requirement for countries receiving its economic aid, with the aim of involving communities and citizens and rendering them, to some extent, co-deciders of the measures adopted. Participation in decision-making encourages the introduction of new levels of democratic participation, especially in countries unfamiliar with democratic practices. At the same time, participation allows stakeholders to play a decisive role in public decision-making processes. This has been the most significant institutional outcome attained by a long cultural campaign conducted in the last decades of the twentieth century, a campaign demanding a new role for citizens and their full involvement in decision-making processes as signs of a truer democracy. All this lay in continuity with an American tradition. In the United States, voice was given to 'public interest' already in the 1970s thanks to the so-called public interest movements. ${ }^{63}$ These, rather than speaking of 'general and abstract' notions, represented a form of lobbying for the people. In other words, in the United States issues concerning

62. S. Cassese, The Global Polity, p. 160.

63. See E. S. Clemens, The People's Lobby. Organizational Innovation and the Rise of Interest Group Politics, The University of Chicago Press, Chicago, 1997. 
the public interest have emerged through lobby-like organizations and mobilizations. Indeed, the actions of lobbies themselves have often been interpreted as an 'act of representation'. ${ }^{64}$

\section{...and Exclusions}

Governance implies, therefore, a kind of political and legal organization that requires a high capacity of mobilization mainly based on interest. However, neither all parties nor all societies possess such an aptitude in equal measure, since this is derived from cognitive, informational and entrepreneurial abilities that are unequally distributed. It is not difficult to realize that, in this type of organization, large organized interests with great resources and with strong pressure capabilities are particularly favoured. It is no coincidence that Europe has chosen to pursue the path of subsidiarity in order to create a positive integration between the ability of subjects to mobilize and the ability of public institutions to make up for their deficiency. ${ }^{65}$

There is, therefore, somesort of ambivalence with regards to governance processes and their relationship with democracy. This is clearly shown by the fact that the literature on the topic is divided between the celebration of the participation surplus that it promotes and the legitimacy deficit it suffers. Following von Hayeck, ${ }^{66}$ neoliberal thinkers have discredited all great political projects and economic planning as a sign of authoritarian politics taking away from individuals and civil society efficiency, initiative, vitality and freedom. Governance coincides with the crisis of politics and political parties ${ }^{67}$ that is, the collectors of political demands. It mirrors a version of politics that renounces to pursue grand projects, limiting itself to facilitate the implementation of several small projects born within civil society. The transition from politics as a general and all-encompassing project for society, based on an ideal type, to a policy essentially construed as a managerial activity pursuing specific targets and operated by subjects driven by interests, is a crucial point in understanding the modes of inclusion and exclusion of governance processes.

64. See J. M. Berry, Lobbying for the People, Princeton University Press, Princeton, 1977, p. 5.

65. See M. Cartabia, N. Lupo, A. Simoncini (eds.), Democracy and Subsidiarity in the EU National Parliaments: Regions and Societies in the Decision-making Process, Il Mulino, Bologna, 2013, and especially A. Simoncini, "Beyond Representative Democracy: The Challenge of Participatory Democracy and the Boundless Galaxy of Civil Society”, pp. 45-73.

66. F. A. von Hayeck, The Road to Serfdom, Routledge, London, 2001.

67. G. Preterossi, La politica negata, Laterza, Roma-Bari, 2011, and Id., "Crisi economica globale e spoliticizzazione”, in L. Bazzicalupo, A. Tucci (eds.), Il grande crollo, pp. 85-92. 
The participatory dimension of governance is not so generalized and salvific as it may seem prima facie. The entrance of civil society-or rather of some of its components-in the realm of government implies a (more or less pronounced) privatization of public decision-making. Governance is not easily reconciled with representative democracy and with its own promise of a 'general and abstract' inclusion. In a way, inclusion through participation is always 'particular and concrete'. Indeed, this form of participation in the decision-making clearly implies an exclusion since the decision itself is no longer tied to a mandate relating to major political issues affecting the entire community or significant parts of it. On the contrary, it pertains to problems of specific groups or of local communities or even single persons. Thus it follows specific inputs. Moreover, the call for participation in governance processes, along with the values proper to the notion of democracy 'from below', promotes a transformation of citizens into stakeholders with regards to specific issues. Therefore it promotes a version of the public decision as an 'arena' in which participants are allowed to enter because of their particular and egoistic interests. ${ }^{68}$

Governance is a complex institutional phenomenon that transcends participation. First, it implies, beyond the privatization of the decision-making process, significant outsourcing of several public functions. ${ }^{69}$ When considering 'governance', it is therefore necessary to consider not only decision modes that are open to the participation of private entities, but also the actual outcomes of the delegation to private subjects of functions that in the past were carried out by the state. In other words, private subjects manage many tasks that were once considered to be public. Here we find ourselves in a particularly sensitive area, where governance may have significant consequences on a people's fundamental rights and might deeply affect the distribution of resources within society. Let us consider, for example, the consequences of privatization in at least three sensitive areas: the entrepreneurial conduct of transnational corporations operating in countries without regulations protecting labourers nor the environment; ${ }^{70}$ the privatization of prisons that, particularly in the United States, has led to a significant reduction of the protection of inmate rights; the governance of financial markets, where phenomena of 'moral hazard' have had devastating effects. ${ }^{71}$

\footnotetext{
68. See S. Cassese, La crisi dello stato, especially pp. 20 and ff. and pp. 74 and ff., where the notion of 'public arena' is examined in some detail. The image of the public arena is also used in D. Cefai, "Qu'est ce qu' une arène publique? Quelques pistes pour une perspective pragmatiste”, in D. Cefai, I. Joseph (eds.), L'héritage du pragmatism. Conflits d'urbanité et épreuves de civisme, Editions de l'Aube, Paris, 2002, pp. 51-83.

69. A. C. Aman Jr., "Politics, Policy and Outsourcing in the United States: The Role of Administrative Law", in L. Pearson, C. Harlow, M. Taggart (eds.), Administrative Law in a Changing State: Essays in Honour of Mark Aronson, Hart Publishing, Oxford, 2008, pp. 205-221.

70. See P. Zumbansen, "Lochner Disembedded: The Anxieties of Law in a Global Context", in Indiana Journal of Global Legal Studies, 20, 2013, pp. 1-28.

71. R. A. Posner, A Failure of Capitalism: The Crisis of ' 08 and the Descent into Depression, Harvard University Press, Cambridge
} 
In other words, governance might be considered an opportunity for new forms of democratic commitment for citizens, groups, and various subjects; however it might also represent a new form of democratic disengagement inasmuch as the privatization of decisions implies a rejection of the social responsibility criteria, endangering the fundamental rights of individuals. Furthermore, the reference to single issues, mostly of a local and particularistic nature, contributes to a general de-politicization of society, hidingbroader political issues from the public eye. Governance management tasks, which are difficult to trace back to a coherent project, inevitably devour the idealistic and ideological charge of European politics.

With the collapse of grand projects and the end of ideological politics, governance marks the end of political conflict as well. Governance, in other words, is inherently pacifying, as Czempiel has noted. ${ }^{72}$ It might even be argued that governance constitutes a kind of insurance against conflict itself. First, this is the result of the involvement in decision-making of stakeholders, who thus become, to some extent, co-decision makers. Furthermore, major conflicts are expunged from the scenario of governance, or made less noticeable, through its division or localization. As Zumbansen has remarked, "governance conflicts are regularly disembedded by confining them to a particular context, governed by rules of competence and authority." ${ }^{73}$ Obviously, every specific governance context has its own greater or smaller share of conflict which, however, is related to the specificities of the various contexts rather than to great political and ideological issues.

Governance might be considered a way of managing power based on 'economic' modes and aiming at 'effectiveness, ${ }^{74}$ that is, doing "things, without resorting to legal force." ${ }^{75}$ It does not only seek solutions to problems through specific arrangements without engaging on the theoretical and ideological plane; it also sets up its responses to problems with the least possible expenditure of political resources. In this sense, "success or failure, rather than legitimacy or illegitimacy, now become the criteria of governmental action." 76 There is, therefore, an economy inherent to governance that consists

\footnotetext{
(Mass.), 2009. On the relationship between financial crisis and governance processes, see M. R. Ferrarese, "La crisi finanziaria tra stati e mercati e il "mondo 3" dell'economia globale", Democrazia e diritto, 3-4, 2012, pp. 15-40.

72. E.-O. Czempiel, “Governance and Democratization”, in J. N. Rosenau, E.-O. Czempiel (eds.), Governance without Government, pp. 250-271.

73. P. Zumbansen, "Lochner Disembedded: The Anxieties of Law in a Global Context", p. 5.

74. On the notion of 'effectiveness' see, A. Catania (ed.), Dimensioni dell'effettività. Tra teoria generale e politica del diritto, Giuffrè, Milano, 2005, and Id., Diritto positivo ed effettività, Editoriale Scientifica, Napoli, 2010 and Effettività e modelli normativi. Studi di filosofia del diritto, (published by Valeria Giordano). Also see A. Catania, Metamorfosi del diritto. Decisione e norma nell'età globale, Laterza, Roma-Bari, 2008.

75. E.-O. Czempiel, “Governance and Democratization”, p. 250. Also see O. R. Young, "The Effectiveness of International Institutions”, in J. N. Rosenau, E.-O. Czempiel (eds.), Governance without Government, pp. 160-194.

76. M. Foucault, The Birth of Biopolitics: Lectures at the Collège de France. 1978-79, Palgrave Macmillan, Basingstoke, 2008,
} 
in saving power and resources. On the one hand, 'decision', which in the past was a sign of political sovereignty entailing an expenditure of power up to the ultimate test of the Schmittian 'state of exception', with governance seems to become a co-decision. On the other hand, a large part of the costs of enforcement is reduced through the (greater or lesser) convenience that the co-deciders find in implementing the rules.

Considerably purified of the coercive disposition of power, governance appears to be part of a framework in which "sanctioning instruments and regulatory potentials typical of the states take place through a variable geometry, with very different degrees of effectiveness." 77 Governance might be identified with 'governmentality' as defined by Foucault, a soft mode of governance that relies on 'regimes of truth' that are, as much as possible, 'natural', that is, close to or coinciding with self-regulation. All behaviors, even those of governments, need to maintain flexibility and adaptability. In this way, they turn into a kind of "exercise of possibilities", even if they maintain a normative character-as noted by Bazzicalupo. ${ }^{78}$ The rules, therefore, are not given a priori, but are the result of negotiations and of adaptive behaviors that take into account the needs of the governed, following the model of the Christian pastorate. ${ }^{79}$ The results of the struggle are the results of the specific decisions and ways of being of the actors involved and of the different competitive environments. They enshrine the idea that "the living, as such, is in its immanence unrepresentable", and that, however, "it never represents a power of the laws that is creative, generative, undetermined that inhabits the living itself; a power of the singularity differentiating itself from the forms it takes on." ${ }^{80}$ Here lies the true change that governance has imposed - especially in Europe - in the legal field, thoroughly disrupting the institutional structure of 'the modern'.

\section{What Juridical Strategy for Governance?}

In the institutional changes taking place in recent decades, states have been protagonists as much as victims. On the one hand, they have contributed to the increasing liberalization

\footnotetext{
p. 16. Also see L. Bazzicalupo, Il governo delle vite. Biopolitica ed economia, Laterza, Roma-Bari, 2006 and Politica Rappresentazioni e tecniche di governo, Roma, Carocci, 2013.

77. F. Mancuso, Le 'verità' del diritto, p. 81.

78. L. Bazzicalupo, 'Le linee mobili di confine nella normatività sociale e la indeterminatezza delle procedure', in A. Tucci (ed.), Disaggregazioni, pp. 29-46.

79. M. Foucault, Sécurité, territoire, population.

80. L. Bazzicalupo, "Le linee mobili di confine nella normatività sociale e la indeterminatezza delle procedure", p. 43. Italics in the text.
} 
of legal and economic life through a series of reforms, laying the foundations of a system of laws à la carte that encourages increasingly widespread processes of forum shopping, shopping law and competition between different jurisdictions. ${ }^{81}$ Sassen has spoken of 'denationalization' precisely to indicate the tendency of states to "reorient their particular policy work or broader state agendas toward the requirements of the global economy even as they continue to be coded as national." ${ }^{22}$ On the other hand, while states were gradually being de-nationalized, the concept of rule of law was being internationalized. Its new use turned it into an institutional brand expendable on the global plane for the protection of rights and even for the protection of the market, ${ }^{83}$ sometimes leading, rather paradoxically, to situations of lawlessness. ${ }^{84}$ So, some of the elements of the rule of law are either imposed by international organizations on to the weak states, or become the object of a 'transplant' made in exchange of economic benefits. ${ }^{85}$

The juridical strategy of governance requires the combination of a large number of legal codes in order to provide legal instruments that adapt to specific and increasingly different situations. The obfuscation of the primacy of law, with the view of entrusting many of its tasks to other legal instruments more capable of meeting the needs of a changing and fluid normativity, was inevitable. Such a change was mainly due to functional reasons. The demands coming from an internationalized market and from complex societies could not be met by rigid, predefined and centralized legal instruments - as those produced by the European states. There was, moreover, a discrepancy between the now 'global' extent of problems and dynamics and the 'territorial' scope of legislation. Finally, there was a temporal need, since long legislation processes were incompatible with the speed of the market. ${ }^{86}$ But even political reasons required the use of legal instruments detached from the state and its legislation - tools that were lacking the strong symbolic meanings and the public resonances weighing down and slowing the legislation. More generally, variegated and agile legal instruments, made up of parts each capable of satisfying the specific needs of the different social groups, were required.

\footnotetext{
81. See: A. Zoppini (ed.), Concorrenza tra ordinamenti giuridici, Laterza, Roma-Bari, 2003, A. Plaia (ed.), La competizione tra ordinamenti giuridici, Giuffrè, Milano, 2007, and F. Viola, La concorrenza tra gli ordinamenti e il diritto come scelta, Editoriale Scientifica, Napoli, 2008. Also M. Gnes, La scelta del diritto. Concorrenza tra ordinamenti, arbitraggi, diritto comune europeo, Giuffrè, Milano, 2004.

82. S. Sassen, Territory, Authority, Rights, p. 223, and pp. 230 and ff.

83. G. Palombella, È possibile una legalità globale? Il rule of law e la governance del mondo, Il Mulino, Bologna, 2010.

84. U. Mattei, L. Nader, Plunder: When the rule of law is illegal, Blackwell, Oxford, 2008.

85. See, on this, G. Ajani, "Navigatori e giuristi. A proposito del trapianto di nozioni vaghe”, in V. Bertorello (ed.), Io comparo, tu compari, egli compara. Che cosa, come, perché?, Giuffré, Milano, 2013, pp. 3-20.

86. See F. Ost, Le temps du droit, Odile Jacob, Paris, 1999. Also M. R. Ferrarese, Il diritto al presente, Il Mulino, Bologna, 2002. On the new spatial-temporal order, see S. Sassen, Territory, Authority, Rights, pp. 378 and ff.
} 
The need was felt for a re-orientation, through institutional mechanisms of 'disaggregation', which rendered possible for the legal relationships to no longer be construed around 'territories' or people'. It was necessary, in other words, to seek dynamic legal solutions capable of moving in-between different legal spaces and orders, influencing each other, taking on different forms and even overcoming the boundary between public and private.

If the framework of contemporary global legality offers the viewer a remarkable variety of ways of being of the law, ${ }^{87}$ governance processes contribute not only to enrich the picture, but also to connote its meaning by producing its own legal models. For example, besides the mode of 'government', other traditional juridical modes based on 'factuality' seem to remerge, ${ }^{88}$ such as "hidden hands, habits, patterned behavior, and cultural mores." ${ }^{\prime 9}$ In a context that abandons the rigor of clear conceptual distinctions and general and abstract characteristics, even Europeans return to legal mores and other forms of ius non scriptum m $^{90}$ to respond to "complex conflict situations that cannot be managed hierarchically and in a centralistic way." ${ }^{11}$ Supiot refers to neo-feudal characteristics as specific elements of the current legal context and of governance phenomena characterizing it. ${ }^{92}$ Even the soft law widely adopted in Europe, ${ }^{93}$ by directly contradicting the notion of "law command" evoked by Austin as well as Kelsen's idea of "sanction" - two concepts that belonged to the European 'punitive' language ${ }^{94}$ - represents an epochal transition.

Here, we wish to draw attention upon two other important modes used by governance: contract law and judge-made law. These two less visible modes, belonging to the

87. On this, M. R. Ferrarese, Prima lezione di diritto globale, Laterza, Roma-Bari 2012.

88. On factual law, see P. Grossi, L'ordine giuridico medievale, and Id., "Diritto, globalizzazione, scienza giuridica", in Foro italiano, 5, 2002. Also see, M.R. Ferrarese, Le istituzioni della globalizzazione. Diritto e diritti nella società transnazionale, Il Mulino, Bologna, 2000; M. Vogliotti, Tra fatto e diritto. Oltre la modernità giuridica, Giappichelli, Torino, 2007; R. Marra, "Per una scienza di realtà del diritto (contro il feticismo giuridico)", in Materiali per una storia della cultura giuridica, n. 2, 2008.

89. On the question of polycentrism and polyarchy, see K. J. Holsti, "Governance without Government: Poliarchy in Nineteenth-Century European International Politics”, in J.N. Rosenau, E.-O. Czempiel (eds.), Governance without Government, p. 32 .

90. S. Mader, Ius non scriptum, Editoriale scientifica, Napoli, 2011. Also see S. M. Carbone, Il diritto non scritto nel commercio internazionale. Due modelli di codificazione, Editoriale scientifica, Napoli, 2012.

91. C. Joerges, "Integrazione attraverso la de-giuridicizzazione? Un intervento interlocutorio", in M. Blecher et al. (eds.), Governance, società civile e movimenti sociali, Ediesse, Roma, 2009, p. 45.

92. A. Supiot, Homo juridicus: Essai sur la fonction anthropologique du Droit, Seuil, Paris, 2005.

93. L. Selden, Soft Law in European Community Law, Hart, Oxford, 2004. Also, D.M. Trubek-L. G. Trubek, "Hard and Soft Law in the Construction of Europe: The Role of the Open Method of Coordination", in European Law Journal, 11, 2005, pp. 343-364; G. Bronzini, "The Social Dilemma of European Integration”, and S. Sacchi, 'Governance e coordinamento aperto delle politiche sociali', both in M. Ferrera, M. Giuliani (eds.), Governance e politiche dell'Unione europea, Il Mulino, Bologna, 2008.

94. M. Foucault, La société punitive. Cours au Collège de France. 1972-1973, Seuil-Gallimard, Paris, 2013. 
legal vocabulary of modernity, significantly contribute to give governance a legal physiognomy. They respond perfectly well to the idea of 'soft revolution', a scheme that operates through implied, indirect and partial rather than explicit, direct and all-encompassing reforms. It is no coincidence that their importance and the number and significance of their tasks have significantly increased in today's globalized world. The strong presence of different types of contracts and of judge-made law also responds to the need for legal forms that bear little political connotation, variable and capable of different combinations between the public and private parts. Jurisdiction and contract may allow for less restrictive and less defined rules than statutes. Moreover, they are legal methods of composition capable of reconciling and balancing different interests. They also allow for a greater feasibility in temporal terms. Whereas the law was projected into the future, a future it tended to shape rigidly, governance enjoys a greater feasibility over time. It might correspond to the short-termism of economic life, and at the same time might rapidly correct those legal responses that fail to work properly. Contract and judiciary law both have the necessary elements to become real forms of 'contract governance' and 'judicial governance' that is to work as responding to public issues. ${ }^{95}$ In order to meet the various demands of governance, contract and judicial law, while continuing to survive in their typical form, have nonetheless undergone profound changes that make them more difficult to relate to the original model developed in the European states. Beyond the 'typical' form, contract and judiciary law have also been variously reproduced, even giving rise to apocryphal versions of the original model. This has taken place in order to respond to the changing needs of different kinds of subjects, and to adapt to the global dimension of the issues at stake. Two references will suffice to give an idea of these changes. With regard to contracts, we range from the importance of the lex mercatoria in the globalized world ${ }^{96}$ - which is nothing more than a modeling of contract usages for international trade purposes - to the many outsourcing contracts - through which states and other public institutions bestow on private subjects various tasks and responsibilities which in the past were considered to be public. ${ }^{97}$ With regard to judicial

\footnotetext{
95. On governance "by contract" there is a vast literature. See the special issued of the Indiana Journal of Global Legal Studies, 14, 2007, on 'Governing Contracts. Public and Private Perspective', and the special issue of the Law and Contemporary Problems, 2, 2013 on 'The Public Dimension of Contract: Contractual Pluralism Beyond Privity'. On these two forms of governance, see my book La governance tra politica e diritto.

96. See F. Galgano, La globalizzazione nello specchio del diritto, Il Mulino, Bologna, 2003; F. Galgano, F. Marrella, Diritto del commercio internazionale, Cedam, Padova, 2011; F. Marrella, La nuova lex mercatoria. Principi Unidroit e usi nei contratti del commercio internazionale, Cedam, Padova, 2004. Also see M.R. Ferrarese, Diritto sconfinato, pp. 76 and $\mathrm{ff}$. 97. See, for example, S. Chesterman, A. Fisher (eds.), Private Security, Public Order: The Outsourcing of Public Services and Its Limits, Oxford University Press, Oxford, 2009; Martha Minow, Jody Freeman (eds.), Government by Contract: Outsourcing and American Democracy, Harvard University Press, Cambridge (Mass.), 2009.
} 
governance, we might refer not only to the expansion of different types of international courts, ${ }^{98}$ but also to the tasks they perform, including law-making functions. ${ }^{99}$ It is also worth mentioning that the judicial formula has also had an impact on a number of private dispute resolutions, such as arbitration, mediation by 'quasi-judicial' agencies that perform crucial tasks in today's world. ${ }^{100}$

To sum up, the requirements of governance promote the combination of a large number of legal regulations, so that instruments capable of adapting to the specificity and to the variability of concrete situations may become available. The variability of regulations may refer to the degree of formality of the law (encompassing the social, the private, the public/private, the public, etc...), or might be of spatial kind (ranging to the local, regional, national, international, supra- and trans-national level).

\section{Governance and 'Strategic' Legal Forms}

Contract law and judge-made law might be thought of as two heirs sharing the legacy of legislation, dispersing the abstractness and generality of rules as well as the theological nature of law itself. Inspired by the 'here and now' principle, they are far removed from any 'political theology' and from any other form of transcendence. ${ }^{101}$ In fact, the law of governance consists of rules that have no dogmatic character; they no longer come from 'elsewhere'. They are, on the contrary, a product of the actions of competing individuals and groups motivated by specific goals and interests. Above all, judicial and contract law have become crucial in today's world for their ability to adapt in a twofold way to the ongoing tendency towards privatization. On the one hand, they provide an important role to private subjects, albeit each in different ways. On the other, both are capable of promoting and satisfying the 'legal entrepreneurship' of subjects, something typical of American history and that corresponds to the economic nature that global capitalism has forced onto institutions. ${ }^{102}$

\footnotetext{
98. Cassese remarks that in the last few decades international jurisdictional organisms have grown from six to more than twenty, while there ten 'almost jurisdictional' organisms. See S. Cassese, Global Polity.

99. On the point, M. Shapiro, A. Stone Sweet, On Law, Politics, and Judicialization, Oxford University Press, Oxford, 2002, and S. Cassese, I tribunali di Babele. I giudici alla ricerca di un nuovo ordine globale, Donzelli, Roma, 2009.

100. See M. Shapiro, Courts: A Comparative and Political Analysis, The University of Chicago Press, Chicago, $1981 ;$ B. Caplan-E.P. Stringham, "Privatizing the Adjudication of Disputes", in Theoretical Inquiries in Law, vol. 9, 2008, consulted on line on 1 February 2014 at http://www.bepress.com/til/default/vol9/iss2/art8. Also see H. Muir-Watt, "Economie de la justice et arbitrage international", in Revue de l'Arbitrage, 3, 2008, pp. 389-418.

101. A. Supiot, Homo juridicus, pp. 92 and ff.

102. On the economic penchant of global law, see my entry "Globalizzazione", in Enciclopedia delle scienze sociali, Istituto
} 
The transposition of the 'language of interest' in the legal field takes place thanks to the growing importance of contract and judicial law, which assign a direct role to subjects and reward their dynamism and interactive abilities. ${ }^{103}$ In other words, and referring back to Elster, it might be said that judge-made law and contractual dynamics both make use of the language of 'negotiation', ${ }^{104}$ and contemplate 'strategic' forms of action. This regards actors acting in situations of mutual dependence, each one trying to read the moves of the others in response to their own. In fact, every actor is pursuing his own selfish purposes through a competitive interaction with the other parts, a process that has been analyzed by game theory. ${ }^{105}$ As it is known, such 'games' even contemplate the possibility that individuals resort to 'threats', misrepresentations, false statements and other strategies that belong to the repertoire of war in order to challenge the counterpart and eventually win. In a way, in the forms of strategic action the subjects no longer obey a 'command'. On the contrary, they are encouraged to act so as to produce legal results (sentences, contracts, etc...) in line with their own aims, that is, the maximization of utility and affirmation of their own interests. With reference to the game theory framework, it might be said that the rules of governance are no longer supported by a 'parametric rationality' but by a 'strategic rationality.' ${ }^{106}$

While legislative law pretended to offer a single, coherent solution, a unique and generalized response to a specific problem or a given social demand, the rules emerging from contracts and court decisions are strongly influenced by the competitive environment that generates them and by the skill and strategic capabilities of the parties partaking to the competition. They represent contingent and particular responses that cannot be immediately generalized and may not be immediately applied to other situations. Strategic rationality also affects public law, which is also drawn towards forms of strategic action and is subject to economic analysis. ${ }^{107}$ These strategic modes have

dell'Enciclopedia Italiana Treccani, Roma, 2001, pp. 156a-166a. Alos see my works "Il diritto americano e l'imprenditorialità dei privati", in Politica del diritto, 1, 1995, pp. 97 and ff., and "An Entrepreneurial Conception of the Law? The American Model through Italian Eyes”, in D. Nelken (ed.), Comparing Legal Cultures, Aldershot, Dartmouth, 1996.

103. See my Le istituzioni della globalizzazione, pp. 32 and ff.

104. J. Elster, Argomentare e negoziare, Anabasi, Milano, 1993. See A. Zoppini (ed.), Concorrenza tra ordinamenti giuridici, Laterza, Roma-Bari, 2003, A. Plaia (ed.), La competizione tra ordinamenti giuridici, Giuffrè, Milano, 2007, and F. Viola, La concorrenza tra gli ordinamenti e il diritto come scelta, Editoriale Scientifica, Napoli, 2008. Also see M. Gnes, La scelta del diritto. Concorrenza tra ordinamenti, arbitraggi, diritto comune europeo, Giuffrè, Milano, 2004.

105. D. M. Kreps, Game Theory and Economic Modelling, Oxford University Press, Oxford, 1990. For a useful introduction, offered from the perspective of political theory, see G. Rusconi, Scambio, minaccia, decisione. Elementi di sociologia politica, Il Mulino, Bologna, 1984.

106. A more philosophical perspective is offered by T. Magri, Contratto e convenzione. Razionalità, obbligo, imparzialità in Hobbes e Hume, Feltrinelli, Milano, 1994.

107.See R.C.Cooter, The Strategic Constitution, Princeton University Press, Princeton, 2000. Also G. Napolitano, M.Abbrescia, Analisi economica del diritto pubblico, Il Mulino, Bologna, 2009. 
gradually gained importance, while sectors of 'public' law have been to judicial devices - often identifiable as so many forms of governance.

The emphasis on the strategic nature of the subjects' actions, especially in the context of judicial and contractual governance, reflects a strong depletion of the regulatory horizon of law itself. The notion of legality, ${ }^{108}$ largely deprived of the guiding light of legislation, is today more than ever a 'myth. ${ }^{109}$ It sometimes takes refuge under the 'light constitutional cloak,' ${ }^{110}$ which refers to a 'network' ${ }^{111}$ or to a 'fabric' made of various auctoritates and rationes. ${ }^{112}$ This is especially true with reference to the international scenario, where states and other various international structures are engaged, within a contractual framework, in collaborating and competing with one another. Consequently, the notion of legality is subject to challenges and forms of exploitation while performing functions that limit power in the name of rights. ${ }^{113}$ In legal relations, the crucial weight of interests and the turn towards strategic rationality may seem to contradict the constitutional turn that characterizes our own time. Yet rights and interests are the great combination buttressing the political and institutional organization based on governance. ${ }^{114}$ The imbalance between these two components also represents the imbalance between normative and strategic attitude in current legal relations.

All this leads us to reconsider Weber's prediction that capitalism would always rely on the "complete calculability of the functioning of public administration and law" ${ }^{115}$ as a condition to ensure "the highest degree of formal calculability." ${ }^{116}$ On the contrary, it is in a spectrum of extremely differentiated choices, methods, practices and legal rules, in accordance with different criteria and rationalities, that today's capitalism reserves the right to make its own decisions depending on the circumstances. Governance, in this great indeterminacy, represents a vast reservoir for this extreme juridical differentiation.

108. The literature on the issue of legality is constantly growing. See, for example, M. Vogliotti, "Legalità", in Enciclopedia del diritto, Giuffrè, Milano, 2013.

109. P. Grossi, Mitologie giuridiche della modernità, Giuffrè, Milano, 2001.

110. B. Sordi, "Il principio di legalità nel diritto amministrativo che cambia", in Diritto Amministrativo, 1, 2008, pp. 1-28.

111. B. Pastore, "Le fonti e la rete: il principio di legalità rivisitato", in G. Brunelli, A. Pugiotto, P. Veronesi (eds.), Scritti in onore di Lorenza Carlassare. Il diritto costituzionale come regola e limite al potere, Jovene, Napoli, 2009, pp. 257-280.

112. M. Vogliotti, "Legalità", p. 420.

113. G. Palombella, Ė possibile una legalità globale?

114. This combination indicates the juxtaposition of 'the rights of possibilities', i.e. the legal instruments that follow the language of interests, and the 'the law of necessity', i.e. those parts of the law that still sets strict limits to human action, such as the preservation of the environment.

115. M. Weber, Economy and Society, p. 162.

116. M. Weber, Economy and Society, p. 85, where computability is linked to the formalistic culture of the legal class rather than to the needs of the economic life, and where the auxiliary role played by it in capitalist development is appreciated. 